\title{
Psychometric evidence of the transcultural adaptation of the Vulnerability Abuse Screening Scale (VASS) for the detection of violence against the elderly
}

Rodrigo da Silva Maial Eulália Maria Chaves Maia ${ }^{2}$

Abstract

Objective: to present preliminary psychometric evidence of the cross-cultural adaptation of the Vulnerability to Abuse Screening Scale. Method: The steps of cultural adaptation verified conceptual, item, semantic and measurement equivalence. For measurement equivalence and verification of the psychometric data of the study samples of 30 and 66 elderly persons, respectively, were used. Descriptive and inferential statistics (KR-20, T-Student Test, Pearson correlation, univariate ANOVA and the Fleiss' Kappa Index) were used for analysis of results. Results: It was found that the age of the participants ranged between 60 and 84 years, with a majority of older women participants $(n=38)$. The KR-20 value for the overall score of the instrument was 0.688 . The values for the four dimensions proposed by the authors of the instrument were 0.528, 0.289, 0.552 and 0.303 , respectively. Only the values of the subscales Vulnerability and Coercion proved to be close to those of the original study (0.550 and 0.390). Conclusion: The internal consistency values found in the present study ranged from moderate to good, indicating that the results were satisfactory, despite being initial findings.

Universidade Federal do Rio Grande do Norte, Centro Universitário FACEX - UNIFACEX. Natal, RN, Brasil.

2 Universidade Federal do Rio Grande do Norte, Programas de Pós-Graduação em Ciências da Saúde (PPGCSA) e Psicologia (PPGPSI). Natal, RN, Brasil.

Correspondence

Rodrigo da Silva Maia

Email: rodrigo_maia89@yahoo.com.br

Keywords: Violence. Elderly. Elder Abuse. Questionnaire. Psychometrics. 


\section{INTRODUCTION}

Population aging is a global phenomenon. Simultaneously, there is a need to guarantee opportunities for health, social participation and social security in a continuous manner throughout life, with the development of public policies aimed at comprehensive care for the elderly. These should provide assistance in the fields of social security, pensions, health, education and all the other fundamental rights established by relevant legislation ${ }^{1}$. However, comprehensive protection for the elderly is not currently guaranteed, especially in the context of ill-treatment and violence against this population.

Violence is growing worldwide, permeating, in an expressive manner, interpersonal relationships and relations between groups. As a social and systemic phenomenon which is subjective and triggers social contradictions, violence needs to be understood both in its expression and in terms of the impact on those affected by it. The World Health Organization (WHO) promulgated a classification that has been widely used by elderly care services ${ }^{2,3}$, according to which violence against the elderly can be classified as physical, psychological or emotional - which includes verbal violence - sexual, economic or financial, and as neglect and self-neglect ${ }^{4}$.

In addition, despite being a growing phenomenon with increasing social and media visibility, difficulties are still encountered in screening, identifying and preventing violence. Among the reasons for the difficulty in screening, arising from a shortage of information and problems in registering complaints, and which are listed in literature as the main agents that create an underreporting of violence, are a degree of proximity and/or kinship between the aggressor and the victim, or the presence of an affective-emotional, caregiving, or financial type dependent relationship ${ }^{3,5}$.

It is worth noting that violence against the elderly is usually only verified when a complaint is made and verified by means of examinations that assess, in an exaggerated manner, signs and indications of physical ill-treatment only. Factors that suggest the evidence of violence of other kinds, such as psychological or financial aspects and/or neglect and self-neglect, are not considered.
As there is a clear lack of instruments available in Portuguese for the detection of domestic violence against the elderly, it seems opportune and relevant to make available and adapt Lusophone versions of tools derived from consistent research programs ${ }^{6}$. One of the programs recognized for developing a tool for violence tracking ${ }^{7-9}$ produced the Vulnerability Abuse Screening Scale (VASS), based on studies by Schofield et al..$^{10}$ and Schofield and Mishra ${ }^{11}$, in Australia. This scale is the object of the proposal of the current study.

The VASS instrument was created based on modifications of the Hwalek-Sengstock Elder Abuse Screening Test. The VASS contains twelve dichotomous items that, through the self-reports of the elderly, establish the risk of domestic violence. Data collection is based on the perception that the elderly person has regarding everyday situations that can indicate if they are a victim of violence. The point score of the scale is obtained through the sum of the values assigned to each affirmative answer, except for items 4, 5 and 6 , which score in the event of a negative answer.

The items seek to identify the phenomenon through four domains, namely Vulnerability (items $\mathrm{N}^{\circ} 01$ to $\mathrm{N}^{\circ} 03$ ), Dependence ( $\mathrm{N}^{\circ} 04$ to $\mathrm{N}^{\circ} 06$ ), Dejection $\left(\mathrm{N}^{\circ} 07\right.$ to $\left.\mathrm{N}^{\circ} 09\right)$ and Coercion (item $\mathrm{N}^{\circ}$ 10 to $\left.\mathrm{N}^{\circ} 12\right)$. These, in turn, try to explain four of the six WHO classifications: physical, psychological and financial violence and neglect. VASS is therefore a short screening tool for abuse of the elderly, which can be used in a clinical and home context, and aims to establish the risk of violence.

The psychometric evidence studies of validity and precision were examined in a longitudinal research process ${ }^{11}$. The psychometric findings of the instrument in question were found to be satisfactory and adequate for the adaptability of the scale to other cultural contexts

In this context, the present study aims to present preliminary psychometric evidence of the crosscultural adaptation of VASS, which investigates the risk of domestic violence against the elderly. Specific objectives were applied to evaluate the equivalence measurement of the Brazilian version, including: 1) Evidence of validity based on the internal structure of the Brazilian version of the instrument, through 
analysis of the internal consistency of this version compared with the original instrument; 2) Evidence of apparent or face validity, by measuring the statistical agreement between the evaluation of the judges; 3) An initial evaluation of factors related to evidences of validity based on the correlations (convergence patterns) and differentiations (discriminant patterns)

\section{METHOD}

A study with a methodological, transversal and analytical design was performed. The steps for cross-cultural adaptation followed the proposals of Herdman, Fox-Rushby and Badia ${ }^{12,13}$ and used the methodological propositions of other authors about adaptation, such as Beaton, Bombadier, Guillemin and Ferraz, Guillemin, Bombadier and Beaton $^{14,15}$. This model is based on the evaluation of conceptual, item, semantic, operational and measurement equivalence, and has been widely disseminated throughout Brazil, especially in research involving the elderly ${ }^{16}$. Data about the substages of conceptual, item and semantic equivalence can be seen in a recent publication ${ }^{17}$.

\section{Operational equivalence}

With respect to the operational equivalence substage, which involves performing a pre-test of the proposed synthesized version, we sought to evaluate the degree of comprehension and acceptability of the Brazilian version of the instrument among a group of specialist judges who had participated in the previous stages. This group was formed by postgraduate students in Psychology, who are familiar with the cross-cultural adaptation method, as well as being knowledgeable in gerontology, human development and instrument validation studies, and a group of elderly people. A population of elderly people with different social, economic and educational characteristics was chosen, so that a final or revised synthesis-version could be confirmed and thus the final formatting of the adapted instrument confirmed.

\section{Measurement equivalence}

Next, the measurement equivalence, although partial, of the instrument was undertaken. At this

stage, the preliminary psychometric evidence of the instrument was investigated with a larger population of elderly persons, statistically verifying its internal consistency and preliminary validity evidence.

\section{Sample}

The samples of the elderly persons participating in the two stages were independent. In other words, the elderly participants of the operational equivalence stage were different from those of the measurement stage. These individuals were selected for convenience from services of health, social care and organized civil society. All were located in the metropolitan area of the municipality of Natal, Rio Grande do Norte. To define the sample participants the suggestion of the authors of the Transcultural Adaptation proposal was considered in the pre-test stage. This recommends the use of around 30 to 40 participants ${ }^{14}$, to delineate the participant sample from the operational equivalence stage of the study. In view of this, 30 elderly people participated in this study.

For the measurement equivalence step, the proposals of five respondents per item, on average, was followed ${ }^{18}$. In the case of the present study, the sample group of this stage should total 60 subjects. In practical terms, however, a total of 66 elderly persons were evaluated, adding $10 \%$ to the value suggested above. In both above steps, the sample comprised those aged 60 years or older who consented, in a clear and free manner, to participate in this research, and who had retained their mental functions. Elderly persons who did not meet the previously mentioned criteria and which interrupted the interview because they were emotionally affected by the subject matter were excluded from the study.

\section{Data collection, protocols and instruments}

Data was collected through interviews, carried out by two previously trained interviewers with a background in psychology. The data of the operational equivalence stage was collected between November and December 2014. The data for the measurement equivalence stage were obtained in January and February 2015. The study was carried out in health and social care units and organized civil 
society centers located in the metropolitan region of the city of Natal, Rio Grande do Norte.

The following instruments were used as protocols: a) A sociodemographic questionnaire, which investigated data such as age, gender, place of birth, years of schooling/educational level, marital status, religion, as well as clinical health characteristics and the self-evaluation of perception of interpersonal relationships; b) The Mini Mental State Exam (MMSE), for screening of cognitive impairment, as this instrument is designed for a rapid and practical clinical evaluation of the cognitive state of geriatric patients, for the application of the inclusion criteria of the study; and c) The Vulnerability Abuse Screening Scale (VASS).

\section{Data analysis}

Regarding data analysis, the Fleiss' Kappa (k) measurement was used to evaluate the judges of the panel of experts, as well as the elderly persons, regarding the comprehension and acceptability of the items, beyond consensus. This evaluates the reliability of the agreement in the evaluations of the judges and measures the apparent or face validity of the instrument. The interpretation of the Kappa coefficient can be classified as: a) Almost perfect agreement, where values are between 0.81 and 1.00; b) Substantial agreement, where they are between 0.61 and 0.80 ; c) Moderate agreement, between 0.41 and 0.60; d) Fair, between 0.21 and 0.40; e) Slight agreement, between 0.0 and 0.20 and no correlation, where values are less than zero (0), indicating an absence of agreement ${ }^{19}$.

The data obtained in the interviews was categorized and analyzed through descriptive statistics, including frequency, percentages, central tendency and dispersion, with the aim of characterizing the participant sample and the other quantitative results. In the case of dichotomous items, internal consistency analysis was performed using the Kuder-Richardson reliability coefficient (KR-20) to evaluate the internal consistency of the instrument. Inferential statistics were applied to verify discriminant and convergent patterns of the studied data using Student's t-Test, univariate
ANOVA and Pearson's correlation, respectively, which were chosen through the verification of the normality of the data, using the Shapiro-Wilk test. Statistics software was used for the analysis of data. The value of statistical significance adopted was equal to or less than $0.05(\mathrm{p}<0.05)$.

\section{Ethical aspects}

The study was performed following the approval of the Ethics Research Committee of the Universidade Federal do Rio Grande do Norte (Rio Grande do Norte Federal University) (No 97.186/2012; CAAE: 05563712.8.0000.5537), and all the participants signed a Free and Clear Consent Form.

\section{RESULTS}

Operational equivalence was satisfactory, with an acceptability of $92.5 \%$ among the elderly population studied, which was a total of 30 elderly people, aged between 60 and 81 [Mean (M): 68.07, Standard Deviation (sd): 5.687 ] years. The reliability of agreement between the judges of the stages was 0.625 (non-elderly expert judges) and 0.585 (elderly judges), respectively. In general, the results presented were acceptable, with values varying from moderate to high, suggesting the surface or apparent validity of the instrument.

Regarding the measurement equivalence stage, the age of the participants ranged from 60 to 84 years old, with elderly respondents $(n=38)$, representing $57.6 \%$ of the sample studied. The number of people sharing a residence with the elderly ranged from one to seven people (M: 4.32; sd: 1.511). The households that the elderly persons lived in have, on average, four to nine rooms (M: 5.80; sd: 0.980). The other sociodemographic data can be seen in Table 1 .

Health data, regarding the hospitalizations, falls and disabilities of the elderly population studied, can be seen in Table 2 .

Data of the evaluation of the perception of the relationship of the individual with different people in their social environment can be visualized in Table 3 . 
Table 1. Sociodemographic data of the population of elderly persons studied, Natal, Rio Grande do Norte, 2015.

\begin{tabular}{|c|c|c|}
\hline Variables & $\mathrm{n}$ & $\%$ \\
\hline \multicolumn{3}{|l|}{ Gender } \\
\hline Male & 28 & $(57.6)$ \\
\hline Female & 38 & $(42.4)$ \\
\hline \multicolumn{3}{|l|}{ Age range } \\
\hline 60 to 64 & 18 & $(27.3)$ \\
\hline 65 to 69 & 14 & $(21.2)$ \\
\hline 70 to 74 & 8 & $(12.1)$ \\
\hline 75 to 79 & 15 & $(22.7)$ \\
\hline$\geq 80$ & 11 & $(16.7)$ \\
\hline \multicolumn{3}{|l|}{ District } \\
\hline North & 15 & $(22.7)$ \\
\hline East & 19 & $(28.8)$ \\
\hline West & 9 & $(13.6)$ \\
\hline South & 9 & $(13.6)$ \\
\hline Rural areas & 14 & $(21.2)$ \\
\hline \multicolumn{3}{|l|}{ Marital status } \\
\hline Single & 1 & $(1.5)$ \\
\hline Married & 45 & $(68.2)$ \\
\hline Widowed & 18 & $(27.3)$ \\
\hline Divorced & 2 & $(3.0)$ \\
\hline \multicolumn{3}{|l|}{ Level of schooling } \\
\hline Never Studied & 13 & $(19.7)$ \\
\hline Primary (Complete or not) & 33 & $(5 ., 0)$ \\
\hline High School (Complete or not) & 14 & $(21.2)$ \\
\hline Higher Education (Complete or not) & 6 & $(9.1)$ \\
\hline \multicolumn{3}{|l|}{ Spend most of the day alone? } \\
\hline Yes & 14 & $(21.2)$ \\
\hline No & 52 & $(78.8)$ \\
\hline \multicolumn{3}{|l|}{ Receive pension or benefits? } \\
\hline Yes & 54 & $(81.8)$ \\
\hline No & 12 & $(18.2)$ \\
\hline \multicolumn{3}{|l|}{ Family income (minimum salary) } \\
\hline Up to 1 & 3 & $(4.5)$ \\
\hline Between 1 and 6 & 39 & $(59.1)$ \\
\hline More than 6 & 24 & $(36,4)$ \\
\hline
\end{tabular}

Created by authors. 
Table 2. Aspects related to the hospitalization, falls and disabilities of the population of elderly persons studied, Natal, Rio Grande do Norte, 2015.

\begin{tabular}{|c|c|c|}
\hline Aspects & $\mathrm{n}$ & $\%$ \\
\hline \multicolumn{3}{|l|}{ Were you hospitalized in the last 12 months? } \\
\hline Yes & 6 & $(9.1)$ \\
\hline No & 60 & $(90.9)$ \\
\hline \multicolumn{3}{|l|}{ Have you suffered a fall in the last 12 months? } \\
\hline Yes & 10 & $(15.2)$ \\
\hline No & 56 & $(84.8)$ \\
\hline \multicolumn{3}{|l|}{ Have you stopped your regular activities in the last 15 days for health reasons? } \\
\hline Yes & 9 & $(13.6)$ \\
\hline No & 57 & $(86.4)$ \\
\hline \multicolumn{3}{|l|}{ Have you been bedridden in the last 15 days? } \\
\hline Yes & 9 & $(13.6)$ \\
\hline No & 57 & $(86.4)$ \\
\hline \multicolumn{3}{|l|}{ Reason for hospitalization, being bedridden or stopping regular activities for health reasons. } \\
\hline Does not apply & 50 & $(758)$ \\
\hline $\begin{array}{l}\text { Respiratory problems, musculoskeletal and/or cardiovascular diseases and/or problems and/or external } \\
\text { causes }\end{array}$ & 11 & $(167)$ \\
\hline Doenças e/ou problemas osteomusculares, cardiovasculares e/ou causas externas & 5 & $(7.6)$ \\
\hline
\end{tabular}

Created by authors.

Table 3. Evaluation of perception of relationships with different people in the social environment of the elderly person, Natal, Rio Grande do Norte, 2015.

\begin{tabular}{lcc}
\hline Evaluation of perception & $\mathrm{n}$ & $\%$ \\
\hline Relationship with partner & 21 \\
No partner & $(31.8)$ \\
Poor & $(12.1)$ \\
Regular & $(31.8)$ \\
Good & 21 & $(24.2)$ \\
\hline Relationship with children & 16 \\
No children & 1 \\
Poor & $(1.5)$ \\
Regular & $(40.9)$ \\
Good & 27 & $(43.9)$ \\
Relationship with grandchildren & 29 \\
No grandchildren & $(13.6)$ \\
Poor & 9 \\
Regular & 3 & $(4.5)$ \\
Good & $(19.7)$ \\
Relationship with other people who live in the home & 13 \\
No other people in home & 32 & $(48.5)$ \\
Poor & $(27.3)$ \\
Regular & 18 \\
\hline
\end{tabular}

Created by authors. 
A minimum variance of zero and a maximum variance of 10 points (M: 3.71; sd: 2.404) were observed for total VASS score. If the scores of international studies are taken as a reference, there is a prevalence of $13.6 \%$ of elderly people with scores that may indicate a risk of violence.
The KR-20 value for the overall instrument score was 0.688 (Table 4). The KR-20 values for the four subscales proposed by the authors were $0.528,0.289,0.552$ and 0.303 , respectively. Only the internal consistency values of the Vulnerability and Coercion subscales, 0.550 and 0.390 respectively, were approximate to those found in the original study.

Table 4. Reliability: internal consistency of Brazilian version of Vulnerability Abuse Screening Scale (VASS) instrument. Natal, Rio Grande do Norte, 2015.

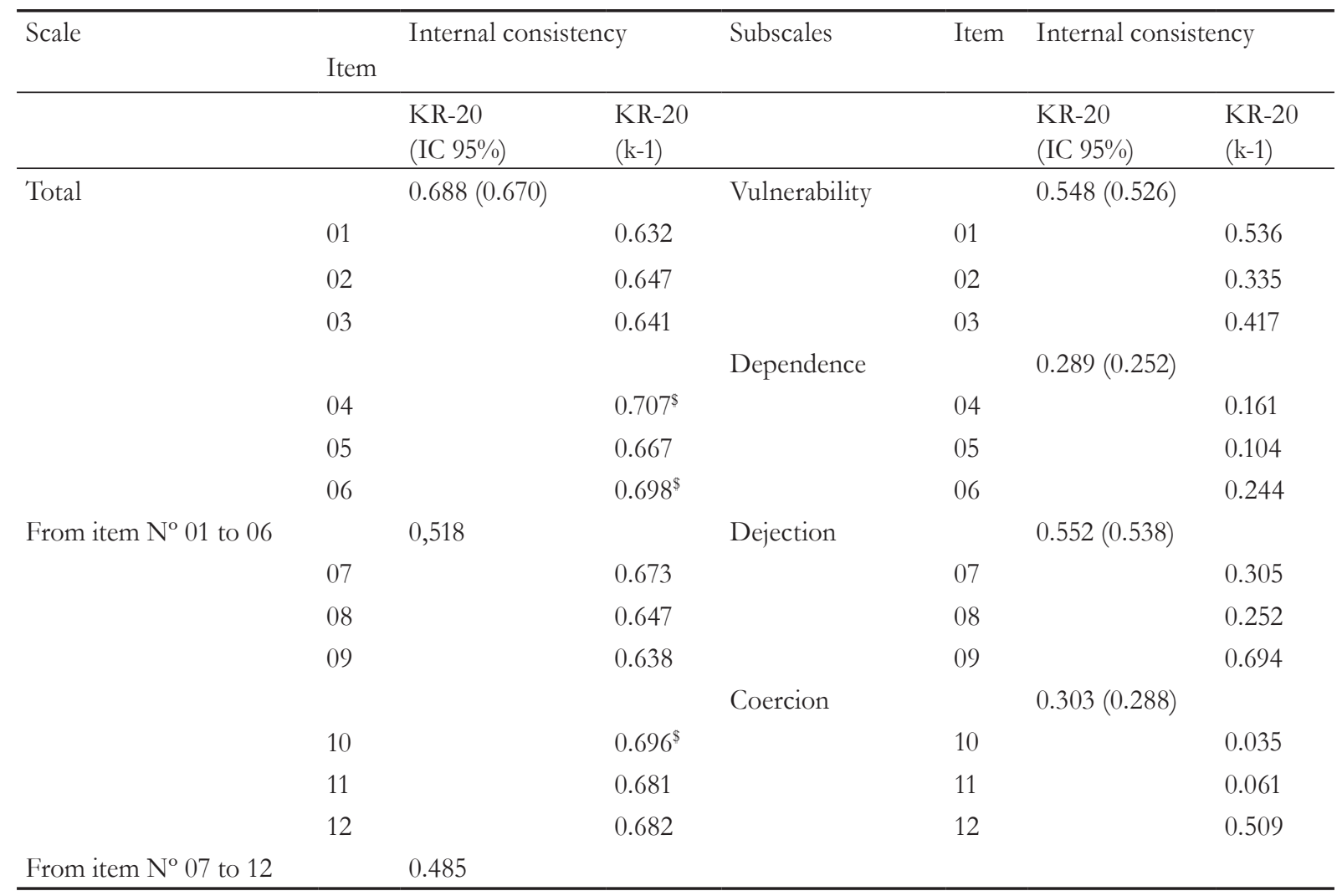

Created by authors.

The removal of items $\mathrm{N}^{\circ} 04, \mathrm{~N}^{\circ} 06$ and $\mathrm{N}^{\circ} 10$ resulted in an increase in the internal consistency index of the total scale. In terms of the internal consistency of the subscales, only the removal of items no. 09, from the Dejection scale, and no. 12, from the Coercion subscale, led to an increase in these values.

Regarding the verification of psychometric properties, the discriminant patterns of the items and external variables were verified in relation to the total VASS score. The Student's t-test was used to verify if there is difference in the total VASS score between certain demographic and social variables, including gender, being alone for most of the day, and hospital admission. Variables such as gender, being alone for most of the day, receiving a pension and/ or benefit, hospitalizations in the last 12 months, having been bedridden in the last 15 days, as with items $\mathrm{N}^{\circ} 01, \mathrm{~N}^{\circ} 03, \mathrm{~N}^{\circ} 06, \mathrm{~N}^{\circ} 07$ and $\mathrm{N}^{\circ} 09$, did not exhibit significant differences in the total score of the scale. The other variables were significant (Table 5).

There was also evidence of the convergent validity of items and external variables in relation to the total score of the scale, which can be seen in table 5. Pearson correlations were used to verify the covariance of the data of each of the items of the instrument with the total VASS score. As expected, to the extent the items on the scale had a positive score, so there was a tendency towards a significant increase in the total score $(\mathrm{p}<0.05)$, except for item no. 06, which did not exhibit this behavior (Table 6). 
Table 5. Mean of Vulnerability Abuse Screening Scale (VASS) and significance of difference with variables studied. Natal-Rio Grande do Norte, 2015.

\begin{tabular}{|c|c|c|c|c|}
\hline Variable & $\mathrm{n}$ & $\%$ & VASS Mean (sd) & $t(p)$ \\
\hline Did you suffer a fall in the last 12 months? & & & & $3.010(p=0,004)$ \\
\hline Yes & 10 & $(15.2)$ & $5.70( \pm 2.983)$ & \\
\hline No & 56 & $(84.8)$ & $3.36( \pm 2.127)$ & \\
\hline $\begin{array}{l}\text { Have you stopped your regular activities in the last } 15 \\
\text { days for health reasons? }\end{array}$ & & & & $2.244(p=0.028)$ \\
\hline Yes & 9 & $(13.6)$ & $5.33( \pm 3.122)$ & \\
\hline No & 57 & $(86.4)$ & $3.46( \pm 2.196)$ & \\
\hline Item $\mathrm{N}^{\circ} 02$ & & & & $6.003(p=0.000)$ \\
\hline Yes & 10 & $(15.2)$ & $7,10( \pm 1.729)$ & \\
\hline No & 56 & $(84.8)$ & $3,11( \pm 1.970)$ & \\
\hline Item $\mathrm{N}^{\mathrm{o}} 04$ & & & & $2.271(p=0.026)$ \\
\hline Yes & 47 & $(71.2)$ & $4.74( \pm 2.023)$ & \\
\hline No & 19 & $(28.8)$ & $3.30( \pm 2.440)$ & \\
\hline Item $\mathrm{N}^{\mathrm{o}} 05$ & & & & $4,589(p=0.000)$ \\
\hline Yes & 19 & $(28.8)$ & $5,58( \pm 2.090)$ & \\
\hline No & 47 & $(71,2)$ & $2,96( \pm 2,105)$ & \\
\hline Item $\mathrm{N}^{\mathrm{o}} 08$ & & & & $5.990(p=0.000)$ \\
\hline Yes & 11 & $(16.7)$ & $6.91( \pm 1.814)$ & \\
\hline No & 55 & $(83.3)$ & $3.07( \pm 1.961)$ & \\
\hline Item $\mathrm{N}^{\circ} 10$ & & & & $2.704(p=0.009)$ \\
\hline Yes & 16 & $(24.2)$ & $5,06( \pm 2.594)$ & \\
\hline No & 50 & $(75.8)$ & $3.28( \pm 2.195)$ & \\
\hline Item $\mathrm{N}^{\mathrm{o}} 11$ & & & & $3,441(p=0.001)$ \\
\hline Yes & 13 & $(19.7)$ & $5.62( \pm 2.534)$ & \\
\hline No & 53 & $(80.3)$ & $3.25( \pm 2.147)$ & \\
\hline Item no 12 & & & & $3.264(p=0.002)$ \\
\hline Yes & 11 & $(16.7)$ & $5.73( \pm 2.573)$ & \\
\hline No & 55 & $(83.3)$ & $3.31( \pm 2.176)$ & \\
\hline
\end{tabular}

Created by the authors.

Table 6. Result of significant correlations between sociodemographic variables, subscales and items of instrument with the total score of the Vulnerability Abuse Screening Scale (VASS). Natal, Rio Grande do Norte, 2015.

\begin{tabular}{lll}
\hline Correlation & $\begin{array}{l}\text { Total VASS Score } \\
\text { Coefficient }\end{array}$ & $p$ \\
\hline Age range & 0.259 & 0.036 \\
\hline Level of schooling & -0.366 & 0.003 \\
\hline Did you suffer a fall in the last 12 months? & -0.281 & 0.022 \\
\hline Item $\mathrm{N}^{\circ} 01$ & 0.704 & 0.000 \\
\hline Item $\mathrm{N}^{\text {o }} 02$ & 0.543 & 0.000 \\
\hline Item $\mathrm{N}^{\circ} 03$ & 0.635 & 0.000 \\
\hline Item $\mathrm{N}^{\text {o }} 04$ & 0.298 & 0.015 \\
\hline
\end{tabular}


continued from table 6

\begin{tabular}{lll}
\hline Item $N^{\circ} 05$ & 0.489 & 0.000 \\
\hline Item No 07 & 0.459 & 0.000 \\
\hline Item N 08 & 0.538 & 0.000 \\
\hline Item No 09 & 0.689 & 0.000 \\
\hline Item N 10 & 0.298 & 0.015 \\
\hline Item No 11 & 0.359 & 0.003 \\
\hline Item No 12 & 0.349 & 0.004 \\
\hline Vulnerability & 0.883 & 0.000 \\
\hline Dependence & 0.573 & 0.000 \\
\hline Dejection & 0.777 & 0.000 \\
\hline Coercion & 0.532 & 0.000 \\
\hline
\end{tabular}

Created by the authors.

\section{DISCUSSION}

The agreement of the evaluations carried out during the semantic equivalence stage, as verified by the Fleiss kappa measure, was 0.625 and 0.585 , which indicates a substantial and moderate agreement, respectively, among the judges ${ }^{19}$. The results of the cross-cultural adaptation of the VASS were satisfactory, indicating the apparent validity of the instrument, which suggests that it is apparently satisfactory for the taking of measurements ${ }^{20}$.

In the measurement equivalence step, a minimum variance of zero and a maximum variance of ten points ( mean $=3.71 ; \mathrm{sd}=2.404$ ) were observed in the total VASS score. If the score values of international studies are taken as a reference, there is a prevalence of $13.6 \%$ of elderly persons with scores that may indicate a risk of violence. The prevalence found here is low compared to the international studies cited, which range from $15 \%$ to $35 \%{ }^{21-25}$. This prevalence is within the averages found in Brazilian studies, which vary from $0 \%$ to $21 \%{ }^{26-28}$.

As Streiner and Norman point out, internal consistency values on the scale of those found in this study, which showed moderate to good internal consistency, are commonplace for brief screening instruments. Values higher than those of the present study can only be obtained with the addition of items to the instrument ${ }^{29}$. Urbina points out that estimates below 0.70 may suggest that the score derived from the test may not be reliable ${ }^{30}$. Therefore, it can be inferred that the increase of internal consistency indices due to the withdrawal of an item may indicate that the test may not be precise for the measurement of the desired construct.

The previously described result (Table 3) seems to indicate that the items with significant results $\left(\mathrm{N}^{\circ}\right.$ $02, \mathrm{~N}^{\circ} 04 \mathrm{~N}^{\circ} 05, \mathrm{~N}^{\circ} 08, \mathrm{~N}^{\circ} 10, \mathrm{~N}^{\circ} 11$ and $\mathrm{N}^{\circ} 12$ ) are more sensitive for the detection of the phenomenon in question. On the other hand, the non-significance of the difference of the scores of the five other items $\left(\mathrm{N}^{\circ} 01, \mathrm{~N}^{\circ} 03, \mathrm{~N}^{\circ} 06, \mathrm{~N}^{\circ} 07\right.$ and $\mathrm{N}^{\circ} 09$ ) may indicate the reverse (Table 1$)$.

For Cohen, these results emphasize the care the interviewer must take regarding false negative or positive results which can exist among respondents of the screening scale in question, especially due to the number of items on the scale. The author concludes that this type of tool should be used with parsimony and only as a preliminary step in the screening and identification of cases that merit indepth investigation ${ }^{7,8}$.

As expected, to the extent the items on the scale had a positive score, so there was a tendency towards a significant increase in the total score, except for item no. 06, which did not exhibit this behavior. The same behavior was observed for the subscales and the total score. This covariance behavior is 
logical and expected. However, the low values, or the nonexistence of a correlation, other than between items $\mathrm{N}^{\circ} 01, \mathrm{~N}^{\circ} 03$ and $\mathrm{N}^{\circ} 09$, highlights the care that must be taken with the results of the scale, regarding the possibility of false negative and/or positive results ${ }^{7,8}$.

It should be noted that falls correlated negatively with the score, although in a very weak manner. Such behavior diverges from the findings in literature, as falls have been related to the phenomenon of violence and/or mistreatment of the elderly ${ }^{31}$.

The main limitation of the study is the lack of a gold standard instrument to test the reliability, sensitivity and specificity of the instrument in question. Despite this limitation, the cross-cultural adaptation and verification of the preliminary psychometric properties of the instrument as a selfreporting measure that addresses the indication of domestic violence against the elderly is relevant, and the results were satisfactory.

\section{CONCLUSION}

It should be noted that these are preliminary results. Following the verification of suitability and the initial psychometric patterns regarding the use of the instrument for the elderly population, there remains a need to continue with the verification of its robust psychometric properties ${ }^{32,33}$. This can be carried out, for example, through analysis of the evidence of reliability in a test-retest situation, and the validity of the construct and criterion. It should be noted that the internal consistency values found in the present study ranged from moderate to good, indicating that the results are satisfactory, even if initial. Finally, it should be emphasized that when the instrument in question becomes available for practical use, it should not be used in isolation in the investigation of violence against the elderly. Instead it should be contextualized and comprise part of an evaluation protocol, which brings together various procedures, instruments and technologies to assist in the detection of violence against the elderly.

\section{REFERENCES}

1. Veras R. Envelhecimento populacional contemporâneo: demandas, desafios e inovações. Rev Saúde Pública [Internet] 2009 [acesso em 20 mai 2015];43(3):548-54. Disponível em: http://www.scielo.br/scielo.php?pid=S003489102009005000025\&script=sci_arttext

2. Correia TMP, Leal MCC, Marques APO, Salgado APO, Melo HMA. Perfil dos idosos em situação de violência atendidos em serviço de emergência em Recife-PE. Rev Bras Geriatr Gerontol [Internet] 2012 [acesso em 25 mai 2015];15(3):529-36. Disponível em: http://www.scielo.br/scielo.php?pid=S180998232012000300013\&script=sci_arttext

3. Gaioli CCLO, Rodrigues RAP. Ocorrência de maus tratos em idosos no domicílio. Rev Latinoam Enferm [Internet] 2008 [acesso em 25 mai 2015]; 16(3). Disponível em: http://www.scielo.br/pdf/rlae/v16n3/ pt_21.pdf

4. Organização Mundial de Saúde. Missing voices: views of older persons on elder abuse. Geneva: WHO; 2002. Disponível em: http://www.who.int/ageing/ publications/missing_voices/en/
5. Sanches APRA, Lebrão ML, Duarte YAO. Violência contra idosos: uma questão nova? Saúde Soc [Internet] 2008 [acesso em 20 mai 2015];17(3):90100. Disponível em: http://www.scielo.br/scielo. php?pid=S0104-12902008000300010\&script $=$ sci_ arttext

6. Paixão Jr CM, Reichenheim ME. Uma revisão sobre instrumentos de rastreamento de violência doméstica contra o idoso. Cad Saúde Pública [Internet] 2006 [acesso em 25 mai 2015];22(6):1137-49. Disponível em: http://www.scielo.br/scielo.php?script $=$ sci_ arttext\&pid=S0102-311X2006000600003

7. Cohen M. Screening Tools for the Identification of Elder Abuse. J Clin Outcomes Manag [Internet] 2011 [acesso em 26 mai 2015];18(6):1-11. Disponível em: http://turner-white.com/pdf/jcom_jun11_abuse.pdf

8. Cohen M. The process of validation of a threedimensional model for the identification of abuse in older adults. Arch Gerontol Geriatr [Internet] 2013 [acesso em 26 mai 2015];57(3):243-49. Disponível em: http://www.sciencedirect.com/science/article/pii/ S0167494313001064 
9. Florência MVDL, Grossi PK. Instrumentos quantitativos validados para a identificação/ rastreamento de violência contra a pessoa idosa. Estud Interdiscip Envelhec [Internet] 2014 [acesso em 26 mai 2015];19(3):1-18. Disponível em: http:// seer.ufrgs.br/index.php/RevEnvelhecer/article/ view/46195/33293

10. Schofield MJ, Reynolds R, Mishra SD, Pawers JR, Dobson AJ. Screening for vulnerability to abuse among older women: women's health Australia study. J Appl Gerontol [Internet] 2002 [acesso em 20 mai 2015];21(1):24-39. Disponível em: http://jag.sagepub. com/content/21/1/24.short

11. Schofield MJ, Mishra GD. Validity of self-report screening scale for elder abuse: Women's Health Australia Study. Gerontologist [Internet] 2003 [acesso em 20 mai 2015];43(1):110-20 . Disponível em: http:// www.ncbi.nlm.nih.gov/pubmed/12604752

12. Herdman M, Fox-Rushby J, Badia X. "Equivalence" and the translation and adaptation of health-related quality of life questionnaires. Qual Life Res [Internet] 1997 [acesso em 25 mai 2015];6(3):24-39. Disponível em: http://link.springer.com/article/10.1023\%2FA\% 3A1026410721664

13. Herdman M, Fox-Rushby J, Badia X. A model of equivalence in the cultural adaptation of HRQoL instruments: the universalist approach. Qual Life Res [Internet] 1998 [acesso em 25 mai 2015];7(4):32335. Disponível em: http://link.springer.com/ article/10.1023/A:1024985930536

14. Beaton DE, Bombadier C, Guillemin F, Ferraz MB. Guidelines for process of cross-cultural adaptation of self-report measures. Spine [Internet] 2000 [acesso em 27 mai 2015];25(24):3186-91. Disponível em: http:// www.emgo.nl/kc/preparation/research\%20design/ vragenlijsten/Beaton.pdf

15. Guillemin F, Bombadier C, Beaton DE. Crosscultural adaptation of health-related quality of life measures: literature review and proposed guidelines. J Clin Epidemiol [Internet] 2003 [acesso em 25 mai 2015];46(12):1417-32. Disponível em: www.ncbi.nlm. nih.gov/pubmed/8263569

16. Maia RSM, Torres RA, Oliveira JGA, Maia EMC. Adaptação transcultural de instrumentos para idosos no Brasil: uma revisão integrativa da literatura. Estud Interdiscip Envelhec [Internet] 2014 [acesso em 26 mai 2015];19(2):359-76. Disponível em: http:// seer.ufrgs.br/index.php/RevEnvelhecer/article/ view/43903/32751
17. Maia RSM, Maia EMCM. Adaptação transcultural para o português (Brasil) da Vulnerability to Abuse Screening Scale (VASS) para rastreio da violência contra idosos. Cad Saúde Pública [Internet] 2014 [acesso em 26 mai 2015]; 30(7):1379-84. Disponível em: http://www.scielo.br/scielo.php?script=sci_ arttext\&pid=S0102-311X2014000701379\&lng=pt\&n $\mathrm{rm}=$ iso\& $\operatorname{tlng}=\mathrm{en}$

18. Hair JF, Anderson RE, Tatham RL, Black WC. Análise Multivariada de Dados. 3 ed. Porto Alegre: Bookman; 2005.

19. Landis JR, Koch GG. The measurement of observer agreement for categorical data. Biometrics [Internet] 1977 [acesso em 25 mai 2015];33(1):15974. Disponível em: http://www.jstor.org/ stable/2529310?seq=1\#page_scan_tab_contents

20. Pasquali L. Psicometria. Rev Esc Enferm USP [Internet] 2009 [acesso em 25 mai 2015];43(n. Esp):992-9. Disponível em: http://www.scielo.br/pdf/ reeusp/v43nspe/a02v43ns.pdf

21. Dong XQ, Simon MA. Is Greater Social Support a Protective Factor against Elder Mistreatment? Gerontology [Internet] 2008 [acesso em 25 mai 2015];54(6):361-8. Disponível em: http://www.karger. com/Article/Pdf/143228

22. Dong XQ, Simon MA. Gender Variations in the levels of Social Support and Risk of Elder Mistreatment in a chinese community population. J Appl Gerontol [Internet] 2010 [acesso em 25 mai 2015];29(6):720-39. Disponível em: http://jag.sagepub. com/content/29/6/720.full.pdf + html

23. Dong XQ, Simon MA. Is Impairment in Physical Function Associated with Increased Risk of Elder Mistreatment?: Findings from a CommunityDwelling Chinese Population. Public. Health Rep [Internet] 2010 [acesso em 25 mai 2015];125(5):743-53. Disponível em: http://www.ncbi.nlm.nih.gov/pmc/ articles/PMC2925012/

24. Dong XQ, Beck T, Simon MA. The associations of gender, depression and elder mistreatment in a community-dwelling Chinese population: the modifying effect of social support. Arch Gerontol Geriatr [Internet] 2010 [acesso em 25 mai 2015];50(2):202-8. Disponível em: http:// www.sciencedirect.com/science/article/pii/ S016749430900082X\#

25. Schofield MJ, Powers JR, Loxton D. Mortality and Disability Outcomes of Self-Reported Elder Abuse: A 12-Year Prospective Investigation. J Am Geriatr Soc [Internet] 2013 [acesso em 20 mai 2015];61(5):679-85. Disponível em: http://www.ncbi. nlm.nih.gov/pubmed/23590291 
26. Duque AM, Leal MCC, Marques APO, Eskinazi FMV, Duque AM. Violência contra idosos no ambiente doméstico: prevalência e fatores associados (Recife/PE). Ciênc Saúde Coletiva [Internet] 2012 [acesso em 25 mai 2015];17(8):2199-2208. Disponível em: http://www.scielo.br/scielo.php?script=sci_arttex t\&pid=S1413-81232012000800030

27. Apratto Jr PC. A violência doméstica contra idosos nas áreas de abrangência do Programa Saúde da Família de Niterói (RJ, Brasil). Ciênc Saúde Coletiva [Internet] 2010 [acesso em 27 mai 2015];15(6):2983-95. Disponível em: http://www.scielo.br/scielo.php?pid=\$1413$81232010000600037 \&$ script $=$ sci_arttext

28. Moraes CL, Apratto Jr PC, Reichenheim ME. Rompendo o silêncio e suas barreiras: um inquérito domiciliar sobre a violência doméstica contra idosos em área de abrangência do Programa Médico de Família de Niterói, Rio de Janeiro, Brasil. Cad Saúde Pública [Internet] 2008 [acesso em 25 mai 2015];24(10):2289-2300. Disponível em: http://www.scielo.br/scielo.php?pid=S0102311X2008001000010\&script=sci_arttext

29. Streiner DL, Norman GR. Health measurement scales: a practical guide to their development and use. 2 ed. Oxford: Oxford University Press; 1995.
30. Urbina S. Fundamentos da testagem psicológica. Porto Alegre: Artmed; 2007.

31. Ribeiro AP, Souza ER, Atie S, Souza AC, Schilithz AO. A influência das quedas na qualidade de vida de idosos. Ciênc Saúde Coletiva [Internet] 2008 [acesso em 20 mai 2015];13(4):1265-73. Disponível em: http://www.scielo.br/scielo.php?pid=S1413$81232008000400023 \&$ script=sci_arttext

32. Almeida ST, Stobäus CD, Resende TL. Adaptação transcultural do Selection, Optimization and Compensation questionnaire (SOC) para aplicação a idosos. Rev Bras Geriatr Gerontol [Internet] 2013 [acesso em 12 jun 2015];16(2):221-37. Disponível em: http://www.scielo.br/scielo.php?script=sci_ arttext\&pid=S1809-98232013000200003\&lng=pt

33. Ramos LMBC, Rocha M, Gomes I, Schwanke CHA. Tradução e adaptação cultural do APQ - Aging Perceptions Questionnaire para a língua portuguesa brasileira. Rev Bras Geriatr Gerontol [Internet] 2012 [acesso em 12 jun 2015];15(2):233-42. Disponível em: http://www.scielo.br/scielo.php?script $=$ sci arttext\&pid=S1809-98232012000200006\&lng=pt

Received: June 18, 2015

Reviewed: January 28, 2016

Accepted: November 11, 2016 